EPJ Web of Conferences 77, 00018 (2014)

DOI: $10.1051 /$ epjconf $/ 20147700018$

(C) Owned by the authors, published by EDP Sciences, 2014

\title{
Construction and in-situ characterisation of high-temperature fixed point cells devoted to industrial applications
}

\author{
Mohamed Sadli ${ }^{1, \mathrm{a}}$, Frédéric Bourson ${ }^{1}$, Ahmet Diril ${ }^{2}$, Christophe Journeau ${ }^{3}$, Dave Lowe ${ }^{4}$ and Clemente Parga ${ }^{3,5}$ \\ ${ }^{1}$ Laboratoire Commun de Métrologie (LNE-Cnam), 61 rue du Landy, 93210 Saint-Denis, Paris, France \\ ${ }^{2}$ TUBITAK Ulusal Metroloji Enstitusu (TUBITAK-UME), Yerleşkesi Barış Mah. Dr. Zeki Acar Cad.1, Gebze, Turkey \\ ${ }^{3}$ CEA, DEN, Cadarache, STRI/LMA, 13108 ST Paul lez Durance, France \\ ${ }^{4}$ National Physical Laboratory (NPL), Hampton Road, Teddington, Middlesex, TW11 0LW \\ ${ }^{5}$ University of Idaho, 1116 Science Center Drive, Idaho Falls, Idaho 83402, USA
}

\begin{abstract}
Among the activities of the European Metrology Research Programme (EMRP) project HiTeMS one work package is devoted to the development and testing of industrial solutions for long-standing temperature measurement problems at the highest temperatures. LNE-Cnam, NPL, TUBITAK-UME have worked on the design of high temperature fixed points (HTFP) suitable for in-situ temperature monitoring to be implemented in the facilities of CEA (Commissariat à l'énergie atomique et aux énergies alternatives). Several high temperature fixed point cells were constructed in these three national metrology institutes (NMIs) using a rugged version of cells based on the hybrid design of the laboratory HTFP developed and continuously improved at LNE-Cnam during the last years. The fixed points of interest were $\mathrm{Co}-\mathrm{C}, \mathrm{Ru}-\mathrm{C}$ and $\mathrm{Re}-\mathrm{C}$ corresponding to melting temperatures of $1324{ }^{\circ} \mathrm{C}, 1953{ }^{\circ} \mathrm{C}$ and $2474{ }^{\circ} \mathrm{C}$ respectively. The cells were characterised at the NMIs after their construction. Having proved robust enough, they were transported to CEA and tested in an induction furnace and cycled from room temperature to temperatures much above the melting temperatures $\left(>+400{ }^{\circ} \mathrm{C}\right.$ ) with extremely high heating and cooling rates (up to $10000 \mathrm{~K} / \mathrm{h}$ ). All the cells withstood the tests and the melting plateaus could be observed in all cases.
\end{abstract}

\section{Introduction}

In the framework of the EMRP joint research project (JRP) HiTeMS "High Temperature Metrology for Industrial Applications" several measurement problems in industrial contexts and at high temperature are being tackled $[1,2]$. The project is organised in five technical work packages and among these one work package, the fourth, is devoted to the implementation and testing of self-validation techniques for non-contact thermometry up to $2500{ }^{\circ} \mathrm{C}$ with a particular emphasis on the use of these techniques for the correction of window transmission changes while measuring temperature by radiation thermometry.

One of the difficulties at the highest temperatures is to monitor temperature in harsh conditions and through windows using radiation thermometers: transmission through windows is often unknown and may evolve as evaporated material is deposited during use of the furnace, especially at the highest temperatures. This is why an in-situ temperature reference can be of great help to many industrial processes [3].

Corrections for varying window transmission are considered using specifically developed high-temperature fixed points in an induction furnace to serve as selfvalidating references [4]. The induction furnace used is part of the facilities of the Severe Accident Mastery Laboratory (LMA) of the CEA (Commissariat à l'énergie atomique et aux énergies alternatives). The furnace works under vacuum or inert gas and the temperature measurements can be achieved either by radiation thermometry through a window or by thermocouples.

Three European NMIs have joined their efforts to develop rugged cells for use in this furnace to allow radiation thermometry measurements through a window, the cells designed to work in the larger temperature gradients and heating/cooling rates used compared to the gradients and heating/cooling rates usually encountered in a metrology laboratory.

The cells were first characterised in the NMI after their construction. Having proved robust enough, they were transported to CEA where they were tested together with additional HTFP cells developed by CEA. The induction furnace was cycled from room temperature to temperatures much above the melting temperatures (as much as $400{ }^{\circ} \mathrm{C}$ above) with extremely high heating and cooling rates (up to $10000 \mathrm{~K} / \mathrm{h}$ ).

\footnotetext{
${ }^{a}$ Corresponding author: Mohamed.sadli@cnam.fr
} 
This paper will summarise the design of the cells and their key features, the filling technique and some of the results of the tests performed in the NMIs and in the facilities of CEA.

\section{Design and filling of the Cells}

This work started with the construction of rugged small-size high-temperature fixed points to serve as insitu calibration devices in inert atmospheres but which would also be stable and robust, even in harsh environments. The cells, constructed in graphite, were designed to fit in the CEA/LMA furnace.

The design of the cells, based on the LNE-Cnam hybrid cell design [5], was adapted to the use in large temperature gradients. The crucible walls were made thicker that in the usual design in order to improve the robustness whereas the length of the cells was reduced so that the likely large temperature distribution effect would be minimized. The outer dimensions are $24 \mathrm{~mm}$ in length and $24 \mathrm{~mm}$ in diameter. The cavity dimensions are $5 \mathrm{~mm}$ in diameter and $15 \mathrm{~mm}$ in length which gives a calculated total emissivity of 0.996 . The emissivity can be increased to 0.999 by adding a diaphragm of $3 \mathrm{~mm}$ diameter at the entrance of the cavity.. Fig. 1 shows a schematic view of the cell.

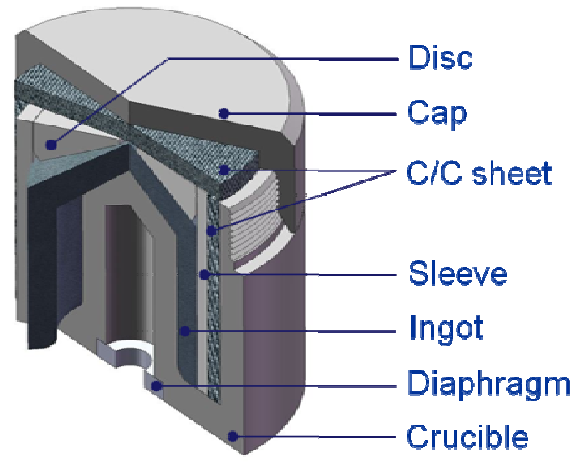

Figure 1. Design of the rugged HiTeMS WP4 HTFP cell adapted from the design for ITS-90 and HTFP cells developed at LNE-Cnam for radiation thermometry.

The cells were filled using the piston method developed by LNE-Cnam [5,6]. This filling technique developed during the last five years and applied to all the recent pyrometric reference cells of the LNE-Cnam from the $\mathrm{Ag}$ point to the $\mathrm{Re}-\mathrm{C}$ point, was developed to cope with three requirements:

1- reduce the risk of contamination by the heating element and the insulation materials

2- allow a fast filling (in one or two steps)

3- ensure a repeatable finalization of the cell after filling.

To achieve these requirements, the filling is performed using a piston which isolates the metal and graphite powder mixture from the potentially polluting furnace elements and insulation and ensures a close-to $100 \%$ filling rate.
This technique was used successfully in the three NMIs (NPL, UME and LNE-Cnam) to fill the HiTeMS high temperature fixed point cells. While LNE-Cnam and TUBITAK-UME used Vega/VNIIOFI type of hightemperature furnace (HTBB-3200PG and HTBB-3500PG respectively) for the filling, NPL used a Chino IR-80 furnace with some modifications to allow LNE-Cnam design crucibles to be filled: some of the insulation was removed, an extended work tube was used and the furnace end piece was adapted (fig. 2).
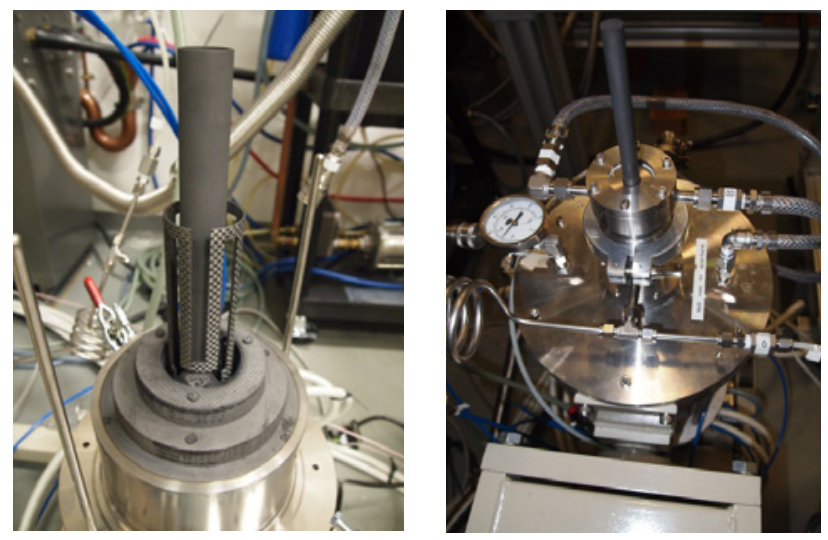

Figure 2. Modifications to the NPL Chino IR80 hightemperature furnace in order to apply the LNE-Cnam piston filling method.

Three different HTFPs were realized for this study and several cells at the fixed-points of Co-C $\left(1324^{\circ} \mathrm{C}\right)$, $\mathrm{Ru}-\mathrm{C}\left(1953{ }^{\circ} \mathrm{C}\right)$ and $\mathrm{Re}-\mathrm{C}\left(2474{ }^{\circ} \mathrm{C}\right)$ were constructed. Tubitak-Ume made $5 \mathrm{Ru}-\mathrm{C}$ cells, NPL made $2 \mathrm{Re}-\mathrm{C}$ cells and LNE-Cnam made $1 \mathrm{Co}-\mathrm{C}, 1 \mathrm{Ru}-\mathrm{C}$ and $1 \mathrm{Re}-\mathrm{C}$ cells

At the end of the filling process the cells were run for several melt/freeze cycles by the NMI to assess the metrological characteristics of the plateaus. In most cases, the repeatability of the melting temperatures and the melting ranges were considered larger than obtained with the conventional design of cells. This is however understandable due to the small dimensions of the cells, the small amount of metal used and the lower purity level of the metals used for the filling of the cells. However for industrial applications the performance was more than adequate.

\section{Characterisation of the Re-C cells developed at NPL}

Two rhenium-carbon cells, HRe\#1 and HRe\#2, made with $5 \mathrm{~N}$ rhenium were constructed, each with two fill cycles. Each cell uses $30.1 \mathrm{~g}$ of rhenium powder and 0.1 $\mathrm{g}$ of graphite powder. Rhenium was from MV Labs, $99.999 \%$ claimed purity and assayed at $\sim 20 \mathrm{ppm}$ total impurities by glow-discharge mass spectrometer. Graphite powder was $99.9999 \%$ nominal purity and was supplied by Alfa Aesar.

Figure 3 shows the last step of the construction of HRe\#2 during which removal of the extension/piston with a diamond cut-off wheel was performed. 


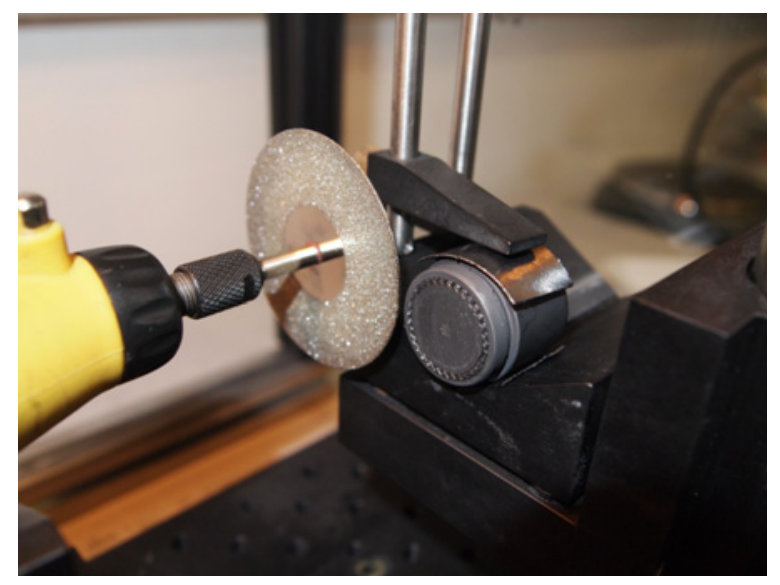

Figure 3. Final step for the realisation of the cells: a diamond cut-off saw is used to remove the graphite extension. The cell can be implemented once the cap closed.

To assess the robustness and repeatability of the cells, they were installed in a 25.4-mm diameter Thermogauge tube furnace. This uses a $25.4-\mathrm{mm}$ internal diameter graphite tube which acts as both a work tube and heater element. A layer of flexible carbon-carbon ceramic $(\mathrm{C} / \mathrm{C})$ cloth is wrapped around the crucible to make a tight fit in the work tube. In front and behind are $35 \mathrm{~mm}$ long insulation pieces made up of interspersed graphite foam and rigid $\mathrm{C} / \mathrm{C}$ with $35 \mathrm{~mm}$ long graphite blocks at the ends. Bored holes give line of sight for furnace control and measurement by radiation thermometer, with argon purge meaning no window needs to be used. The arrangement is as Figure 4.

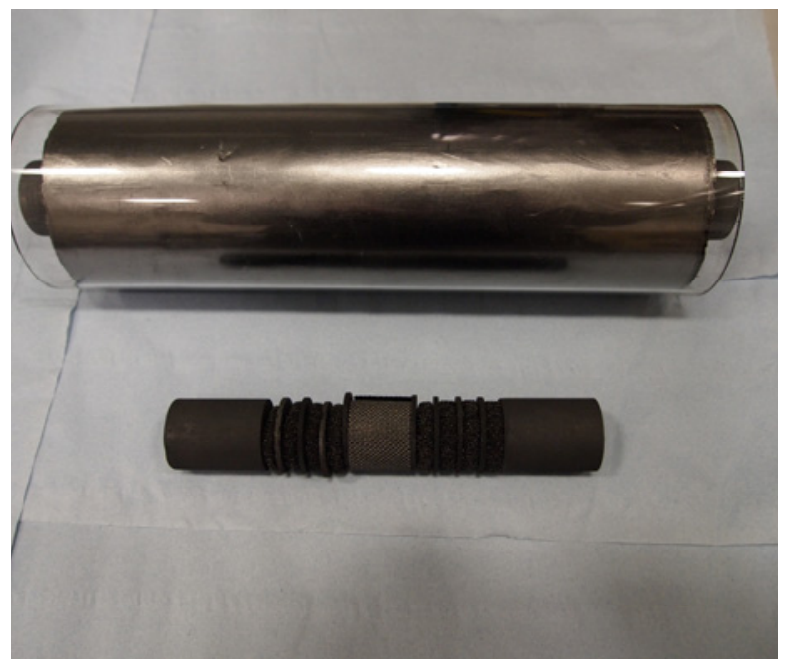

Figure 4: Deployment of insulation in high temperature tube furnace. The furnace worktube/heater is wrapped in graphite felt, then a layer of graphite foil, and the whole enclosed in a fused silica tube.

Temperature measurement was performed with an IKE LP3 radiation thermometer, which can be used with a $650 \mathrm{~nm}$ interference filter with a bandwidth of $25 \mathrm{~nm}$, or a $900 \mathrm{~nm}$ interference filter with a bandwidth of $10 \mathrm{~nm}$. The LP3 has a nominal $1 \mathrm{~mm}$ target size. Size of source standard uncertainty for the $5 \mathrm{~mm}$ aperture of these cells is estimated to be less than $80 \mathrm{mK}$ at $2500{ }^{\circ} \mathrm{C}$.
Normally ramping for this type of cells would be of the order of $20{ }^{\circ} \mathrm{C} / \mathrm{min}$ increase and $15{ }^{\circ} \mathrm{C} / \mathrm{min}$ decrease. These cells were intended to be more robust. So following an initial increase to $\sim 800{ }^{\circ} \mathrm{C}$ in approximately 20 minutes under manual control, the furnace controller was set to ramp up at $50{ }^{\circ} \mathrm{C} / \mathrm{min}$ and down at $70{ }^{\circ} \mathrm{C} / \mathrm{min}$. A further test of robustness was made by shutting power to the furnace at about $2000{ }^{\circ} \mathrm{C}$; cooling to close to room temperature in about $20 \mathrm{~min}$.

Conventionally $\mathrm{Re}-\mathrm{C}$ cells would be prevented from overheating above the melting temperature: deep undercooling is usually observed in that case. In this case one cell was taken up to $2540{ }^{\circ} \mathrm{C}$ to test.

Figure 5 shows a series of melts made with the same furnace offsets. A third order polynomial was fitted to the curve and the melting temperature taken to be the point of inflection in the fit. Repeatability of the melting temperature made under the same conditions over two days was better than. $35 \mathrm{mK}$ for a cell.

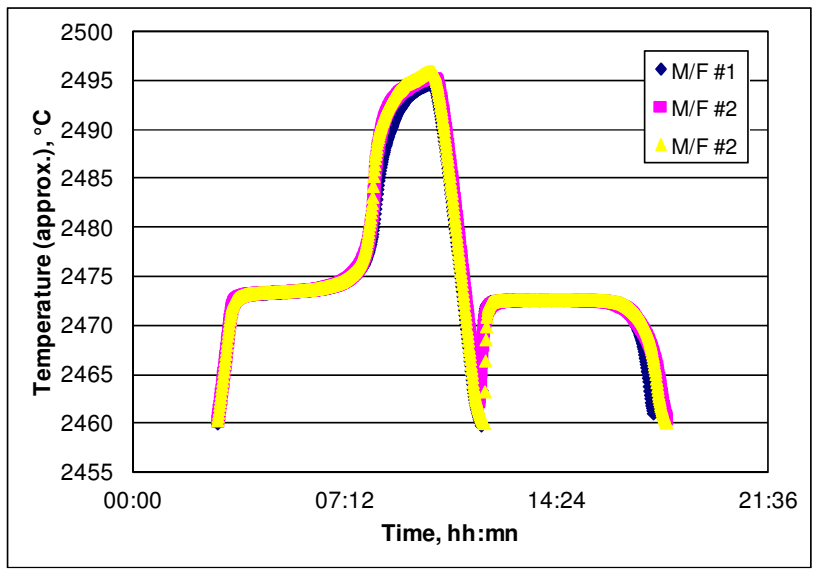

Figure 5: Photocurrent signal as a function of time (using LP3 with $650 \mathrm{~nm}$ filter). Repeated melts with same furnace offsets. One division is approximately $2{ }^{\circ} \mathrm{C}$. Two melts followed normal undercools, one followed undercool to $-200{ }^{\circ} \mathrm{C}$

The melting temperatures of each of the cells was measured and the results were the following: cell HRe\#1 has a melting temperature of $2473.5 \pm 1.2{ }^{\circ} \mathrm{C}$, HRe\#2 a melting temperature of $2473.0 \pm 1.2{ }^{\circ} \mathrm{C}$.

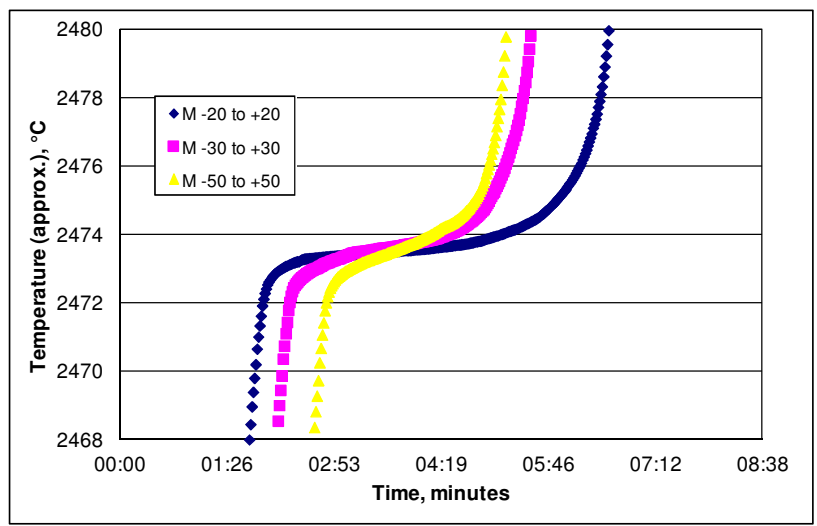

Figure 6: Effect of changing the temperature setpoint at the melt. This effect is considered as negligible. 
One of the features of Re-C is that it usually shows deep undercools of up to $200-300{ }^{\circ} \mathrm{C}$ below the melting temperature if taken substantially (more than $\sim 20{ }^{\circ} \mathrm{C}$ ) above the melting temperature. This was observed for the Re-C cells constructed and studied at NPL. This phenomenon may cause breakage in the case of the conventional cells but is not likely to harm the rugged cells. This was effectively verified during the testing of the cells in this work.

\section{Characterisation of the Ru-C cells developed at TUBITAK UME}

TUBITAK-UME has constructed five Ru-C cells from $99.9 \%$ nominal purity ruthenium powder and $99.9999 \%$ nominal purity graphite powder. Both materials were supplied by Alfa Aesar. Filling of each of the cells was performed in a single step with the piston filling method developed by LNE-Cnam.

Table 1 summarises the masses of the ingots composing the cells. There is only a few grams difference between the five cells. Table 1 shows in particular that the cells were all usable after their filling, even $\mathrm{Ru}-\mathrm{C}-02$ which showed a small crack on the external wall.

Table 1. Details about the five Ru-C eutectic cells filled in TUBITAK UME

\begin{tabular}{|c|c|c|}
\hline Cell & $\begin{array}{c}\text { Purity of the metals } \\
(\%)\end{array}$ & $\begin{array}{c}\text { Mass of the ingot } \\
(\mathrm{g})\end{array}$ \\
\hline $\mathrm{Ru}-\mathrm{C}-01$ & 99.9 & 13.65 \\
\hline $\mathrm{Ru}-\mathrm{C}-02$ & 99.9 & 13.84 \\
\hline $\mathrm{Ru}-\mathrm{C}-03$ & 99.9 & 16.12 \\
\hline $\mathrm{Ru}-\mathrm{C}-04$ & 99.9 & 16.40 \\
\hline $\mathrm{Ru}-\mathrm{C}-05$ & 99.9 & 14.38 \\
\hline
\end{tabular}

Measurements of the eutectic cell plateaus were performed using a VNIIOFI-made radiation thermometer TSP-2 (Transfer Standard Pyrometer) with both $650 \mathrm{~nm}$ and $900 \mathrm{~nm}$ heads. TSP-2 is equipped with adjustable focus assembly from $400 \mathrm{~mm}$ to $1100 \mathrm{~mm}$ and minimum target size is $0.6 \times 0.8 \mathrm{~mm}$ (elliptic field of view). The TSP-2 is calibrated in TUBITAK UME according to ITS90 scale definition, using a copper fixed-point blackbody.

For melting plateaus, the part of the plateau where the first derivative of TSP-2 signal readings with respect to time was relatively stable and close to zero was identified as the actual melting plateau, and only data of this part was considered for calculation of average and standard deviation of plateau values.

Melting and freezing plateau durations were quite short, typically 1 to 3 minutes depending on the furnace temperature offsets ranging from $10 \mathrm{~K}$ to $50 \mathrm{~K}$. The best plateau shapes were obtained with the largest temperature step $(50 \mathrm{~K})$. A typical melt and freeze transition is presented in Figure 7. During the freeze deep undercooling was observed prior to nucleation and freezing, typically in the range of 5 to $10^{\circ} \mathrm{C}$. However for two cells ( $\mathrm{Ru}-\mathrm{C}-3$ and $\mathrm{Ru}-\mathrm{C}-5)$ larger undercooling values of around $35^{\circ} \mathrm{C}$ were observed during some of the cycles.
Varying the thermal conditions of the furnace, namely the size of the temperature steps used to initiate melting or freezing from $10 \mathrm{~K}$ to $50 \mathrm{~K}$, as explained above, or the heating/cooling rates (ranging from $5 \mathrm{~K} / \mathrm{min}$ to $100 \mathrm{~K} / \mathrm{min}$ ) did not show a noticeable effect on the measured melting temperatures.

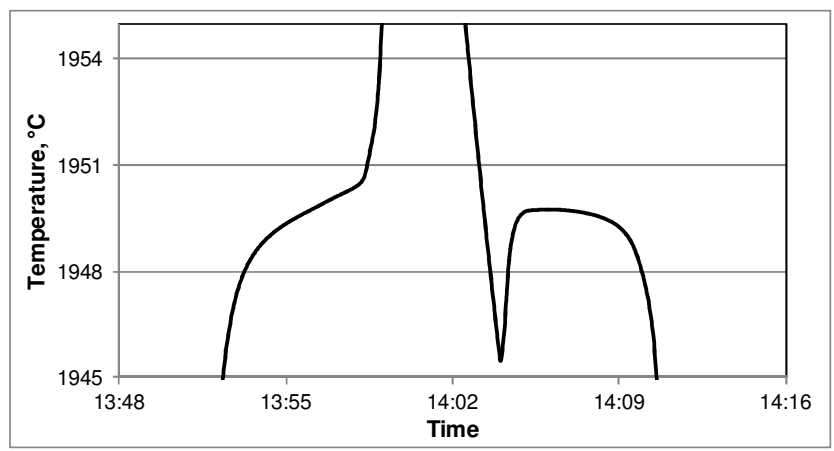

Figure 7. Typical melt and freeze plateaus for the TUBITAK UME Ru-C cells

The freezing temperature was about $20 \mathrm{mK}$ higher than the melting temperature and showed less discrepancy between cells. This also means that in the frame of self-validation methods these cells can be used either at the melt or at the freeze.

\section{Characterisation of the Co-C cell at LNE-Cnam}

LNE-Cnam has developed three cells at the Co-C, Ru-C and $\mathrm{Re}-\mathrm{C}$ points to help assess the differences between the realisations of $\mathrm{Ru}-\mathrm{C}$ and $\mathrm{Re}-\mathrm{C}$ at TUBITAK-UME and NPL respectively. Table 2 summarises the characteristics of the three cells. The $\mathrm{Ru}-\mathrm{C}$ and Re-C cells developed during this project will be compared at a later stage. It is worth noticing that although the cells were of the same design, the Ru-C cell constructed at LNE-Cnam seem to be less completely filled than the $\mathrm{Ru}-\mathrm{C}$ cells filled at TUBITAK UME (Table 1).

Table 2. Information about the three cells constructed at LNE-Cnam

\begin{tabular}{|c|c|c|}
\hline Fixed point & $\begin{array}{c}\text { Purity of the } \\
\text { metals (\%) }\end{array}$ & $\begin{array}{c}\text { Mass of the ingot } \\
(\mathrm{g})\end{array}$ \\
\hline Co-C & 99.998 & 10.47 \\
\hline Ru-C & 99.998 & 11.39 \\
\hline Re-C & 99.997 & 24.53 \\
\hline
\end{tabular}

The focus was first put on the characterisation of the $\mathrm{Co}-\mathrm{C}$ cell. The cell was cycled repeatedly around the melt and freeze plateaux for several days. The objective of these multiple melt and freeze cycles was to assess the robustness of the cell under particularly tough conditions: heating and cooling rates were set at the maximum levels achievable in the Chino IR-80 furnace used for the measurements, reaching about $60^{\circ} \mathrm{C} / \mathrm{min}$ and $-50{ }^{\circ} \mathrm{C} / \mathrm{min}$ respectively and the cell was overheated in the molten state by several hundreds of degrees. 
Figures 8 and 9 show the results of these tests and Figure 10 shows a typical melt-freeze cycle obtained with the Co-C cell.

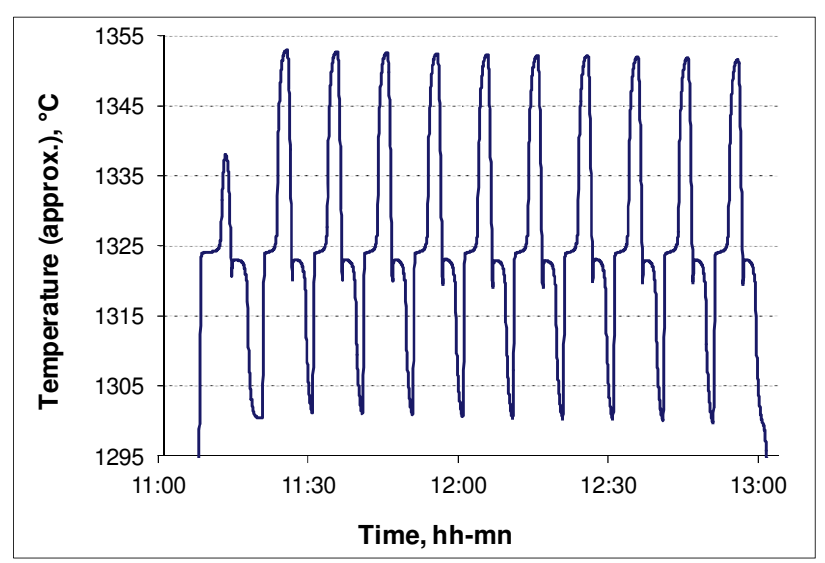

Figure 8. Cycling of the $\mathrm{Co}-\mathrm{C}$ cell allowing to assess the repeatability of the melting temperature (determined at the point of inflection of the melting plateau) to better than $50 \mathrm{mK}$.

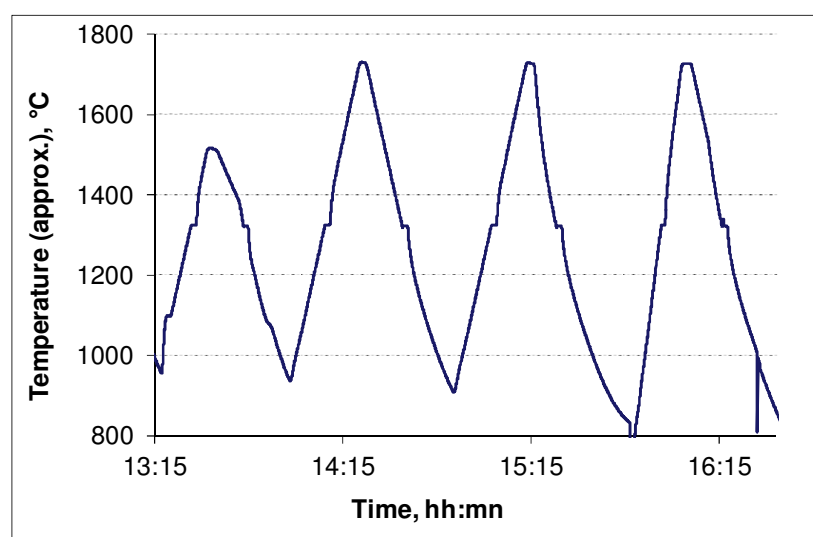

Figure 9. The cell was heated to $1700{ }^{\circ} \mathrm{C}$ approximately: $400{ }^{\circ} \mathrm{C}$ above the melting temperature without any consequence on the melting temperatures or on the integrity of the cell.

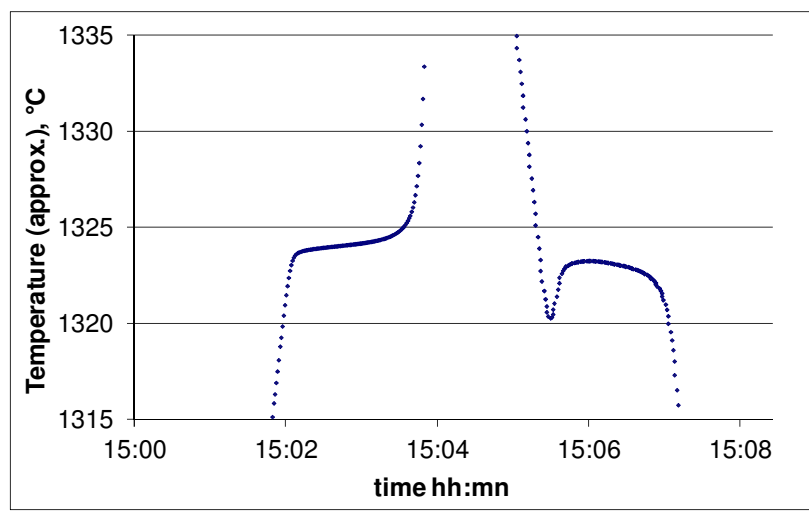

Figure 10. $\mathrm{x}$-axis time, $\mathrm{y}$-axis temperature in ${ }^{\circ} \mathrm{C}$. Performance of a robust $\mathrm{Co}-\mathrm{C}$ of design shown in Figure 7. Plateau duration was of about 1 minute and the melting range was of the order $350 \mathrm{mK}$.

The main output of these preliminary tests was that the Co-C cell, as well as the other cells developed at NPL and TUBITAK UME, was considered to be successfully qualified for use in the facilities of CEA, where they have to withstand more difficult conditions with larger heating and cooling rates, larger temperature gradient and more substantial overheating.

\section{Measurements at CEA}

\subsection{The CEA cells}

The Severe Accident Mastery Laboratory (LMA) is part of the Industrial Reactor Technologies Service (STRI) which depends on the Nuclear Technology Department (DTN) inside the French Atomic Energy Commission. LMA's mission is to improve the available knowledge on nuclear reactor severe accident phenomenology and to understand molten corium behaviour and interaction with reactor components. Corium is a lava-like complex melt compromising fuel, containment and structural materials from the reactor assembly. A severe accident will initiate if there is a failure to remove the fission products' decay heat away from the fuel elements due to malfunction or absence of the cooling system functionality, or loss of coolant.

Within LMA, VITI (VIscosity Temperature Installation) induction furnace was used to implement the cells developed in this project. VITI is the smallest scale facility in PLINIUS (PLINIUS is the only European experimental platform dedicated to the study of severe accidents using large masses of prototypic corium. It consists of 4 facilities: VULCANO, COLIMA, KROTOS and VITI). VITI was initially intended for aerodynamic gas levitation of small droplets of molten materials, but it is also commonly used for material interaction tests (<300grs), in order to gain insight on thermo-physical, chemical properties of materials.

The VITI furnace can function under a medium vacuum or an inert gaseous atmosphere (argon, helium, nitrogen and other gas mixtures containing diluted reactive gases. It allows therefore the use of cells made in graphite crucibles.

The CEA cells were constructed using TM1 graphite from POCO, and the design sketch is given in Figure 11.

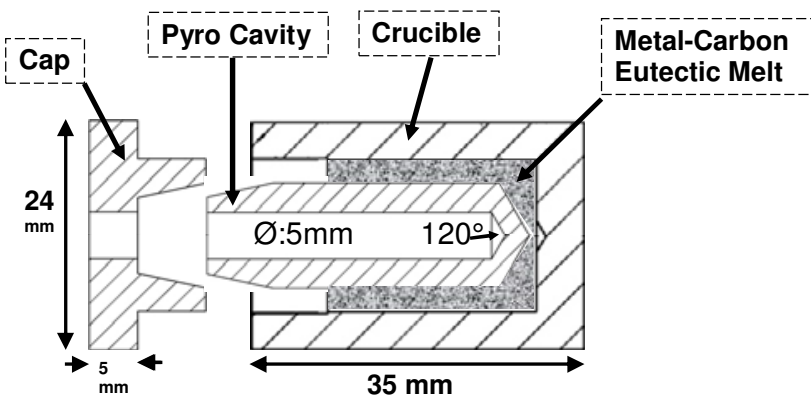

Figure 11. Schematic view of the CEA cells. The cap can be removed between filling steps to allow pouring further powder to obtain larger filling rates.

Table 3 summarises the characteristics of the materials used for the construction of the CEA cells. The filling technique differed significantly from the piston method developed at LNE-Cnam. The cells were mainly intended for vertical operation so the cap could be removed to allow further filling up to the moment where it sticks due to reaction with the eutectic ingot. 
Table 4 shows the final state of the cells. All the cells were constructed with a mixture of metal and carbon at hypoeutectic composition.

Table 3. Characteristics of the materials used for the construction of the CEA cells.

\begin{tabular}{|c|c|c|c|c|}
\hline Material & Shape & $\begin{array}{c}\text { Particle } \\
\text { size } \\
(\mathrm{mesh})\end{array}$ & $\begin{array}{c}\text { Purity } \\
(\%)\end{array}$ & Provider \\
\hline $\mathrm{C}$ & Sponge & 10 & 99,9 & $\begin{array}{c}\text { Alfa- } \\
\text { Aesar }\end{array}$ \\
\hline $\mathrm{Co}$ & Powder & 22 & 99,998 & $\begin{array}{c}\text { Alfa- } \\
\text { Aesar }\end{array}$ \\
\hline $\mathrm{Ru}$ & Powder & 200 & 99,9 & $\begin{array}{c}\text { Acros } \\
\text { Organics }\end{array}$ \\
\hline $\operatorname{Re}$ & Powder & 140 & 99,999 & $\begin{array}{c}\text { Zhuzhou } \\
\text { Kete }\end{array}$ \\
\hline
\end{tabular}

Table 4. Details about the filling rates and mass of crucibles of the CEA cells.

\begin{tabular}{|c|c|c|c|}
\hline Eutectic & $\begin{array}{c}\text { Hypoeutectic } \\
\text { mix Weight } \\
(\% \text { wgt of } \mathrm{C})\end{array}$ & $\begin{array}{c}\text { Total mass } \\
\text { of the } \\
\text { ingot }(\mathrm{g})\end{array}$ & $\begin{array}{c}\text { Estimated } \\
\text { filling rate } \\
(\%)\end{array}$ \\
\hline $\mathrm{Co}-\mathrm{C}$ & 2 & 4,8 & 23 \\
\hline $\mathrm{Ru}-\mathrm{C}$ & 2.25 & 10,1 & 36 \\
\hline $\mathrm{Re}-\mathrm{C}$ & 1.06 & 12,1 & 25 \\
\hline
\end{tabular}

Due to the filling method used at CEA, the filling rates were quite low. We can therefore expect that the cells will be significantly affected by the thermal environment during the phase changes. This has been confirmed during the measurement of the ITS-90 temperatures of these cells performed at LNE-Cnam [7].

\subsection{Results of the tests performed at CEA}

Six of the ten cells developed in this work package were transported to CEA Cadarche (close to Marseille, France) and studied in the VITI induction furnace. The objective was to assess the robustness of the cells and their use for traceability transfer and correction of window transmission [4].

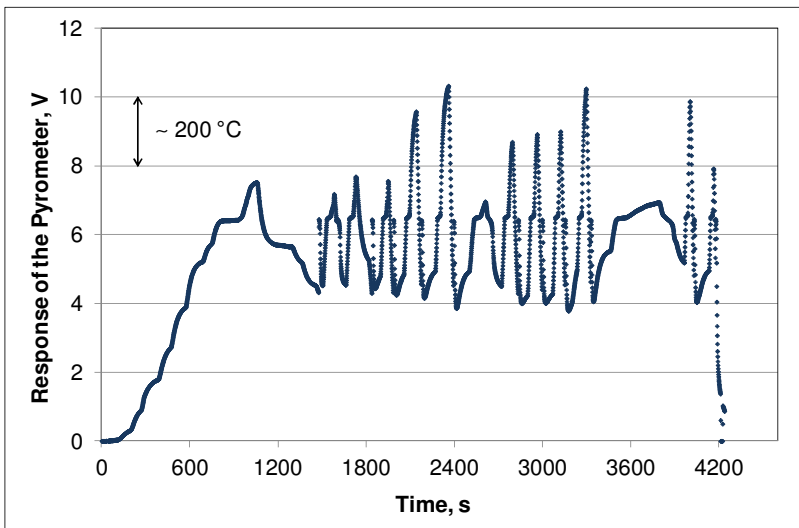

Figure 12. Cycling of the NPL Re-C Cell (Re2) in the VITI furnace.

It is beyond the scope of this paper to go into all the details about these tests but it is important to review the major findings of the work performed in CEA.
The main output is that all the cells produced in the frame of this work and which have been implemented in the VITI furnace withstood, without damage, large heating and cooling ramps of up to $10000 \mathrm{~K} / \mathrm{h}$.

The cycling of the cells around the corresponding melting temperatures was performed. Figure 12 shows a typical pattern of cycling of $\mathrm{Re}-\mathrm{C}$ cells. Moreover overheating could reach $400-500{ }^{\circ} \mathrm{C}$ and the plateaus were still exploitable.

\section{Conclusion and future work}

This work allowed a thorough and complete analysis of the capabilities of high-temperature fixed points to be adapted to an industrial use and yet be able to act as a means for traceability and temperature monitoring in harsh measuring conditions.

The HTFP cells developed in this project and constructed in three different NMIs with the same design of cells and the same filling method have been characterised to assess their reproducibility and their robustness before being transported and tested in the facilities of the CEA, at the Severe Accident Mastery Laboratory in Cadarache. These cells were operated under steep heating and cooling rates and large melting steps causing overheating of several hundreds of degrees. In all cases, the cells performed as hoped and proved robust and reliable.

The next steps of this work will be the comparison of one of the Ru-C cells of TUBITAK UME with that of LNE-Cnam and one of the Re-C cells of NPL with that of LNE-Cnam. This will be an additional check of the reproducibility of the cells.

\section{Acknowledgements}

MS, FB acknowledge funding from the French Metrology Research Programme. DL acknowledges funding from the Engineering and Flow Programme funded by the National Measurement Office. The EMRP is jointly funded by the EMRP participating countries within Euramet and the European Union.

\section{References}

1. http://projects.npl.co.uk/hitems/

2. G. Machin, K. Anhalt, F. Edler, J. Pearce, M. Sadli, R. Strnad, E. Vuelban; "HiTeMS: A pan-European project to solve high temperature measurement problems in industry", In Temperature: Its Measurement and Control in Science and Industry, vol. 8, edited by C. Meyer, 2013, AIP Conf. Proc. 1552, 305 (2013); doi: 10.1063/1.4821383

3.M. Sadli, T. Bellin-Croyat, F. Bourson, T. Deuzé, A. Diril, G. Failleau, C. Journeau, D. Lowe, S. Mokdad, C. Parga, N. Richard " High-Temperature Fixed Points for Industrial Applications" presented at TEMPMEKO 2013. 4. D. Lowe, F. Bourson, C. Journeau, G. Machin, C. Parga, M. Sadli, "Correction for window transmission in radiation thermometry using high temperature fixed 
points", In Proceedings of the International Metrology Conference "Métrologie 2013", Paris, 7-10 October 2013.

5. F. Bourson, S. Briaudeau, B. Rougié, M. Sadli, "Developments around the Co-C eutectic point at LNEINM/Cnam" , Presented at Tempbeijing 2008, Beijing, 20-23 October 2008 (paper 16. CD-Rom)

6. M. Sadli, O. Pehlivan, F. Bourson, A. Diril, K. Ozcan, Int J Thermophys, 30, 36-46 (2009).

7. C. Parga, F. Bourson, M. Sadli, C. Journeau "Cellules à points fixes de température pour la recherche appliquée" In Proceedings of Congrès de la Société Française de Thermique SFT-2013, Gérardmer, 28-31 May 2013. 